Fun, Fearless, Feminist?: An Exploration of Cosmopolitan Magazine's Ongoing Fight for Feminist Legitimacy Within the Changing Landscape of American Feminisms

Amy Ruth Cummings graduated from UCLA with a Bachelor of Arts in Gender Studies in spring 2017. At UCLA, her academic experience in the Gender Studies department was transformative, as were her experiences working in original social science research with the Student Affairs Information \& Research Office and the Undergraduate Research Scholars Program. Her academic interests include feminism, sex \& sexuality, gender and pop culture, as well as how pop culture media can be utilized to teach important information about the world to a wider audience. She is currently working with young women in education and is pursuing continuing study in the field of sex \& sexuality and sexual health education for young people.

Discourse, Public Space, and Politics Regarding the Issue of Korean "Comfort Women": Implications for East Asia Relations

Ann Kim has previously worked as a research assistant at the Wilson Center in Washington, D.C. on broad issues in North Korea and Japan. She is a recent graduate of University of California, Los Angeles with a Bachelor's degree in Political Science with a Concentration in International Relations.

Red Granite Film Financing Scandal: A Case Study in International Corruption

Andres was born and raised in Mexico City and moved to Denver, Colorado when he was 15 years old. He is currently a senior at UCLA majoring in Psychology and minoring in Global Studies. He will be attending Duke Law starting fall 2018 and he hopes to pursue a career in the intersect between entertainment and international business law in the future. 


\section{Evictions in Jakarta Through the Lens of the Media}

Tassaya (Toffy) Charupatanapongse graduated magna cum laude and with Departmental Honors from UCLA in 2017 with a major in Geography and a minor in Global Studies. She wrote her Geography honors thesis on evictions in Jakarta through the media, and traveled to Jakarta in the summer of 2017 as a recipient of the Summer Travel Grant through the UCLA Center for Southeast Asian Studies (CSEAS). She is currently a student at the Graduate School of Education (GSE) at the University of Pennsylvania, pursuing a Master's degree in International Education Development.

Andrew Jarvis is a third-year International Development Studies and Geography double major from Watsonville, CA. He has been involved in research on Jakarta within the Department of Geography since June 2016. He is interested in urbanization, human rights, the geography of tourism, and sustainability. He is currently on exchange through UCEAP in Oslo, Norway and completed an exchange program in Bangkok, Thailand in fall 2017.

A New Neighborhood for an Old City: The Resettlement of the Athenian Agora in the Middle Byzantine Period

Allison Grenda graduated from UCLA summa cum laude in 2017 with a Bachelor of Arts in Communication Studies and a Minor in Art History. As a student at UCLA, she was awarded the university's Undergraduate Research Scholarship for her work on Athenian neighborhood-building in Late Antiquity. Since graduating, Allison has participated in archaeological fieldwork at a Roman forum in southern Italy and has interned in the Education department at the Fine Arts Museums of San Francisco. This summer, she will intern at the UC Berkeley Hearst Museum of Anthropology before beginning a Master's program in Art History at UC Davis in the fall. Allison is passionate about Roman and Late Antique architecture and urbanism and hopes to become a professor of ancient art history. 
Motivation in Los Angeles Factories: Mamá y Papá - What Gets You Up in the Morning?

Yesenia Aguilar Silvan completed her BA in Psychology at the University of California, Los Angles (UCLA) in 2017 and plans to enter a doctoral program in clinical psychology in 2019. Ms. Aguilar Silvan's major clinical and research interests include the dissemination and implementation of evidencebased practices within system-wide reforms, rural settings, and undocumented communities. During her undergraduate career, she worked as a research assistant in the Knowledge Exchange on Evidence-Based Practice Sustainment Lab and the Culture and Anxiety Lab for Mental Health Advances at UCLA, and was a part of various research programs. She also completed a departmental honors thesis entitled "Evidence-Based Practices in Community Settings: An Analysis of Emergent Life Events" and two independent research projects focusing on the mental health of rural Latino youth and undocumented factory workers, which were presented at local and national conferences. During her time at the MGH - PRIDE lab, Ms. Aguilar Silvan has been involved in a National Institutes of Health-funded study assessing an innovative measure of the quality of evidencebased practices such as cognitive behavioral therapy and cognitive processing therapy. She has also been responsible for data management and related research activities. 



$$
\widehat{D S}
$$

